\title{
THE RISE OF PROFESSIONAL PHARMACY IN ISLAM
}

by

\section{SAMI HAMARNEH}

THE emergence of professional pharmacy in medieval Islam as a separate entity from medicine has followed almost the same pattern of development as that which modelled other branches of the health field during this period. But difficulty arose from the fact that there was no clear governmental legislation to prohibit the pharmacist from diagnosing and giving medical treatment to his customers or to restrict the physician from compounding and dispensing drugs to his patients. The charlatan and uncultured from both professions, ${ }^{1}$ not only in rural areas but also in cities, prevented pharmacy from attaining professional status. Nevertheless, in larger hospitals and centres close to governmental supervision retail pharmacists as well as those in hospital and government service enjoyed recognition and prestige.

The seventh century saw the institution and the expansion of the Arabic empire and the wide spread of the new faith, Islam, as the spiritual force behind it. In the early eighth century, Arabic military power reached its climax under the Umayyad dynasty in Damascus. Then the Abbasids took over (750-1258), and the centre of activity moved from Syria to Iraq, where a new era of cultural progress shortly started.

Under Caliph al-Manșūr (754-75), medicine as well as other fields of learning had a strong impetus to develop. With no discrimination for reasons of race or faith, the Galiph encouraged physicians, astronomers, mathematicians, architects and other learned men to cultivate their talents and help to advance intellectual pursuits. Notwithstanding, the first eight years of al-Mansūu's reign were spent in labouring to stabilize and consolidate the Empire. Meanwhile, he accumulated enough riches to launch, in A.D. 762, the building of his new capital city Baghdād, which he called 'Madinat al-Salām' (the city of peace). ${ }^{2}$ It took over four years to complete this magnificent city, ${ }^{3}$ which was destined to become not only the seat of a great empire but also the centre of tremendous cultural activity which kept the torch of ancient learning shining brightly for centuries.

The establishing of the first privately owned apothecary shop, marking the beginning of pharmacy's independence from medicine, has been discussed by a number of eminent historians of the health profession. Many reported ${ }^{4}$ Baghdād to have been the site in A.D. 754 or about $75^{\circ}$ of the first pharmacy shop as the precursor of our modern drug store. ${ }^{5}$ But one need not emphasize the inaccuracy of such dating, for, as we have explained, Baghdād was founded and completed only a little over a decade later. These dates were presumably reported because one coincides with the rise of the Abbasids and the other was al-Manșür's inaugural year. We see therefore, the need for a fresh study of the incentives to and 


\section{Sami Hamarneh}

the nature of the rise of this profession and its consequent development in each particular area of the Islamic domain. The present paper is an attempt to throw light on this issue which is so vital to the history of pharmacy.

Early Arabic sources mention the existence of privately owned pharmacy shops (Dakākin al-Șayādilah) during the reign of al-Manșūr's son, Caliph al-Mahdi (775-85), not very far from the area where the royal palace was located in Baghdād. 6 But a careful study of the records shows that these shops were owned and operated by drug-sellers with no real academic training. They owed their knowledge of the profession rather to wide experience in drug compounding and dispensing. In addition, they practised the organoleptic method of urine analysis for diagnosis, a practice followed by practitioners until early modern times.

Famous among this class of uneducated pharmacists (Sayādilah) was 'Isā Abū Quraysh, who in examining a bottle of urine one day predicted the birth of a male child, ${ }^{7}$ an early unscientific method for diagnosing pregnancy and determining the sex of the embryo through the analysis of urine. Mention is also made of other contemporaries of 'Isā such as Māsawayh, ${ }^{8}$ the father of the famous physician Yūhannā ibn Māsawayh (Mesue the elder); Ishāā, ${ }^{9}$ the father of the great scholar and chief-translator Hunayn; and Sahl, ${ }^{10}$ the father of Sābūr, the author of the first known formulary in Islam for the use of pharmacists in hospitals and retail drug stores. ${ }^{11}$ All of them, we are told, were pharmacists, but we are not sure whether they had any academic training in the profession. The fragmentary reports of at least two of them show that their knowledge of drugs was only through practical experience. ${ }^{12}$ Yet in spite of their lack of academic training, they provided the highest possible medical education available at the time for their children who later on became leading figures in the practice and teaching of Arabic medicine.

This ambitious beginning under the eastern caliphate in Iraq led in the first half of the ninth century to the rise of a new class of true pioneers of educated pharmacists fully alert to the ethical and technical responsibilities of their calling. It is no surprise, for the expansion of the drug and spice trade, the acceleration in the translation of a great number of invaluable medical works into Arabic, and the vigorous intellectual endeavour then cultivated and promoted as never before in Islam, had brought new challenges and opened new avenues of cultural achievements. It also gave rise to a precise and improved synthesis of ancient learning and to the accumulation of new knowledge which made specialization, particularly in the health field, inevitable. ${ }^{13}$ Oculists, ${ }^{14}$ surgeons, ${ }^{15}$ alchemists, ${ }^{16}$ and educated pharmacists, ${ }^{17}$ besides skilled physicians, are reported to have been active in their respective fields. Thus Castiglioni states ${ }^{18}$ that pharmacy 'began its scientific existence with the Arabians because of their special inclination to chemical studies and the great abundance of valuable drugs' pouring into the markets of Islamic cities from countries of the Middle East and the Orient. During the reign of al-Mu'tașim (833-45) it was reported ${ }^{19}$ that educated and morally responsible pharmacists (șayādilah) were granted licences to operate their own drug stores near army camps, while uncultured drug sellers and quacks 


\section{The Rise of Professional Pharmacy in Islam}

were forbidden such privileges. It must be immediately stated, however, that throughout this whole period the two classes existed side by side in all branches of the healing arts. ${ }^{20}$ The uncultured charlatans among pharmacists, for example, constituted, in most cases, the overwhelming majority and disgraced the profession they falsely claimed to represent. As a result, many eminent physicians preferred to compound their own medicines, or had assistants to do the job under their supervision, rather than write them on prescriptions to be prepared in privately owned pharmacy-shops in which they were not always sure of the man in charge. Moreover, the great prestige attained by learned physicians from the rulers and the upper class enticed ambitious students to seek specialization in the healing art without limiting their career to the practice of pharmacy alone. ${ }^{21}$ Therefore, whatever experience they had in the compounding of simples they used in the preparation of medicines for their patients, except for the larger variety of materia medica and those popular pharmaceutical preparations which were normally sought at the apothecary shop.

During this ninth century, nevertheless, pharmaceutical literature reached a high standard of adequacy. Al-Nadìm mentions ${ }^{22}$ a certain Riwāq al-Saydanānī (the pharmacist) who wrote one of the earliest Arabic works on pharmacy, the Book of the Apothecary Art (Kitāb al-Saydanah), which apparently is lost. Yūhannā ibn Māsawayh (d. 857) ${ }^{23}$ as well as Ya 'qūb al-Kindī (d. 873) wrote ${ }^{24}$ treatises closely related to the art of pharmacy. But unlike the Aqräbädhin al-Kabir of Sābūr (d. 869), theirs could hardly be classified technically as formularies. Yet such works demonstrate the authors' acquaintance with and interest in pharmaceutical and chemical techniques. Of great importance to pharmacy in particular, however, was the translation of Dioscorides' Materia Medica ${ }^{25}$ about the middle of the century. It enriched and enhanced the scientific approach to this art throughout the period. Then about the turn of the century Muhammad ibn Zakariyyā al-Rāzì (Latin, Rhazes, d. 925), the greatest clinician of Islam and a pioneer chemist, wrote ${ }^{26}$ several chemical and pharmaceutical treatises of great value to the profession which he acknowledged as separate from medicine. This was over a century before Abū al-Rayhān al-Bīrūnī (973-1048) wrote his monumental Book of Pharmacy in the Healing Art (Kitāb al-Saydanah fĩ al-Tibb). ${ }^{27}$

In this investigation so far we have been using the words apothecary and pharmacy and their derivatives interchangeably both for learned and untrained pharmacists (șayādilah) as the case might be. However, the 'atțärin (perfumers and spicers, also sellers of drugs, mainly medicinal herbs) in Iraq and Persia were specialized in extracting sesame and other oils (adhān) from seeds of plants, as well as the making of butter out of milk, ${ }^{28}$ besides distilling aromatic waters.

These developments no doubt influenced other areas of the Islamic domain. In Syria and Egypt, for example, the shops of the 'atțāin' continued to operate throughout this period of Islamic history and up to modern times. ${ }^{29}$ Meanwhile, a new class of qualified pharmacists was gradually rising to acquire high recognition after the eleventh century, both inside and outside the hospitals and government service. Yet in the first half of the twelfth century, physicians were still reported to have owned and operated pharmacy shops, ${ }^{30}$ 


\section{Sami Hamarneh}

which reminds us of similar cases in the history of American pharmacy during the seventeenth to the nineteenth centuries. However, eminent physicians associated with the Nūri Hospital at Damascus, which contained a well equipped pharmacy (Khizannat al-Adwiyah), ${ }^{31}$ did not compound medicines for their patients. Instead they wrote prescriptions to be dispensed by pharmacists. Names of physicians mentioned in this regard include the one-time hospital director, 'Adb al-Rahim al-Dakhwār, and his associate Radī al-Dīn al-Raḥi bi. ${ }^{32}$

At this time, when the apothecary's art became recognized in Egypt, the output of pharmaceutical literature reached a high standard. In the late twelfth century, Mūsā ben Maymūn (Maimonides, I I 35-1 204) wrote a glossary of drug synonyms and a manual on poisons. ${ }^{33}$ Then at the beginning of the thirteenth century Al-Dustūr al-Bīmäristānī (Hospital Formulary) was completed by al-Shaykh al-Sadìd abū al-Bayān. ${ }^{34}$ Probably the most popular work ever written in Egypt during this whole period as a manual for the apothecary was Minhāj al-Dukkān wa Dustūr al-'Ayān by Abū al-Munā Kohen al-'Atțār in 1259. The last three famous doctors who flourished in Egypt were of the Jewish faith although they wrote their works in Arabic.

In 'Afrīiyah', Tunisia of today, Ishāq ibn 'Imrān (fl. 900), who gained much popularity 'in the knowledge of drugs and the treatment of disease', wrote prescriptions for his patients ${ }^{35}$ to secure their medicines from privately owned apothecary-shops. However, Ahmad al-Jazzār (d. 1009) of al-Qayrawān appointed an assistant to prepare the necessary medicines for his patients, under his supervision. ${ }^{36}$ This was probably either because of fear that his prescriptions would fall into the hands of unqualified 'attaninin', or due to the fact that physicians who sold their own prepared drugs amassed much wealth, especially if their drugs proved successful. For these reasons, many physicians owned pharmacies or had special sections at their 'clinics' for this purpose.

The development of pharmacy in Morocco was similar to that of al-Andalus (the part of the Iberian peninsula under Islamic rule). In both countries physicians throughout the ninth to the eleventh centuries compounded their own drugs. ${ }^{37}$ We are also told ${ }^{38}$ that Ahmad ibn Yunis established by order of Caliph al-Hakam II (reigned 96I-76) a pharmacy shop (called then alKhizānah or Khizānat al-Adwiyah) in a room at the palace. Up to the end of the tenth century, this shop was never surpassed in contents and elegance, in al-Andalus. Ahmad had therein twelve young men working under his supervision to prepare remedies, many of which were dispensed free to the poor. Khalaf al-Zahrāwi (Abulcasis, d. I013) refers to the 'atțārin' repeatedly in his al-Tasriff, with no mention of the educated pharmacists. In the 25th treatise of his work he also reports that the "attāanin' were engaged in the preparation of water and oil-of-roses and other 'adhān' of plants for medicinal use. Later on the 'atțār', depending on his previous education and training, occupied the position of the pharmacist in Morocco and Arabic Spain (al-Andalus). By the second half of the twelfth century we read of the physician Abū Bakr al-Zuhri of Seville ${ }^{39}$ who depended on apothecary shops for his orders. He wrote prescriptions for his patients to obtain the drugs they needed. Thereafter, Ahmad 


\section{The Rise of Professional Pharmacy in Islam}

al-Qurtubi (of Cordova) wrote a book concerning the shop of the 'atțār' entitled Hānüt al-'Attär. ${ }^{40}$

In the great hospital founded about I I 90 in Marrākesh, then the capital city of Morocco, there was a section designed as a pharmacy shop. The manufacturing, compounding and dispensing of drugs were the speciality of trained pharmacists (sayādilah) appointed to the medical staff. ${ }^{41}$ Herbs were cultivated in the hospital's garden for medical consumption. Up to modern times, writings of that period which pertain to pharmacy and the identification and 'virtues' of drugs ${ }^{42}$ continued to be followed uninfluenced by the later Western scientific accomplishments in this field.

In conclusion, one might say that privately owned 'public' pharmacy shops existed in Iraq in the last quarter of the eighth century. Educated, responsible pharmacists are reported almost forty years later. In the second part of the ninth century pharmacy was well recognized as a profession in Persia also. However, charlatans, spice and perfume sellers and drug dealers continued to form a majority. In some cases it is hard to draw the line between the 'atțärin, the drug sellers and spicers, and the retail pharmacist. The fear of physicians that their prescriptions would not be handled properly by untrained ' atțārin' and their hope of material gain by selling their own preparations hampered the progress of professional pharmacy, especially when government supervision was of no effect. Nevertheless, the separation of pharmacy from medicine in Islam, when it was made, was not the result of legislative action enforced by the central government. Rather it was the outcome of a need for specialization in view of expanding trade and knowledge of drugs and the skill required for compounding the various pharmaceutical preparations.

In regard to the West, these developments have played a significant role. The Arabs brought from their homelands new impetus to progress into Sicily during its occupation from the middle of the ninth century to the eleventh. The advanced knowledge embodied in a growing medical literature no doubt became accessible in the island. At that early date, therefore, the stage was set for the edict of the Emperor Frederick II in 1240 in which he gave official recognition to pharmacy in the West as a profession separate from medicine. ${ }^{43}$ It also established standard formularies and governmental supervision of pharmaceutical practice. From the late tenth century al-Andalus became increasingly a centre of great cultural activity. The emergence of professional pharmacy in the twelfth century under Islam led to its further development and maturity in Christian Spain from the thirteenth century onwards. ${ }^{\mathbf{4 4}}$

\section{BIBLIOGRAPHY AND FOOTNOTES}

I. In his Kitäb 'uyūn al-Akhbär, 2, Cario ed., 1925, pp. 100-4, 'Abd Allāh ibn Qutaybah al-Dinawārī (d. 89o) ridicules the irrational approach of untrained practitioners of the time. Muhammad Z. al-Rāzì (d. 925), in the introduction to his treatise on Drugs Found in All Places $F_{\bar{\imath}}$ al-Adwiyah alMawjüdah fi Kull Makān, mentions how uneducated physicians of Iraq and Persia prided themselves on memorizing the names of a variety of drugs in 


\section{Sami Hamarneh}

order to impress their customers by their 'comprehensive' learning. For this reference I wish here to express my gratitude to the library of Yale University for allowing me to consult the Arabic manuscript No. 21052, item 2 of the work mentioned above. For further information on the part played by charlatans during the Middle Ages see Heinrich Schipperges 'Der Scharlatan im arabischen und lateinischen Mittelalter', in Zur Geschichte der Pharmazie, r2, No. 2 (1960), 9-13.

2. Details regarding the establishment and description of this celebrated round city is to be found in Ismā'il al-Dimashqī, al-Bidāalah wa al-Nihāalah (10, Gairo, 1933), 96-97; and Ahmad al-Baghdādì, Tärikh Baghdād (Cairo, 1931), 66-82.

3. Hitti, Philip K. History of the Arabs (6th ed., London, 1958), 292-3.

4. For some insight into this phase of historical investigation I am indebted to Professor Glenn Sonnedecker of the University of Wisconsin, who encouraged me to consult original sources related to the history of Arabic pharmacy. I also wish to thank Dr. Ernst Stieb for checking with me the major works of the nineteenth and twentieth centuries which discuss the rise of professional pharmacy.

5. See, for example, C. J. S. Thompson, The Mystery and Art of the Apothecary (London, 1929), 80; Giulio Conci, Pagine di Storia della Farmacia (Milan, 1934), 351; L. Reutter de Rosemont, Histoire de la Pharmacie d travers les âges (I, Paris, 193I), 123; J. Berendes, Die Pharmacie bei den Alten Kulturvölkern (Halle, 1891), 120-2; and Maurice Bouvet, Histoire de la Pharmacie en France (Paris, 1937), 29-30.

6. Wüstenfeid, Ferdinend. Geschichte der Arabischen Aerzte und Naturforscher (Göttingen, 1840), 12. Wüstenfeld apparently relied mainly on the report by Ahmad ibn abì Ușaybi'ah (1203-70), 'Uyün al-Anbā fi TTabaqät al-Ațibbā, (see 2, Beirut ed., 1957), 79-84, and probably on 'Alī ib̉n Yüsuf al-Qiftī (I 1 72-1248), Ikhbär al-'Ulamā bi Akhbär Al-Hukamā (see Cairo ed., 1326 A.H. [A.D. 1908]), 280-3.

7. Lecler a, Luaien. Histoire de la médecine arabe (I, Paris, 1876), 121.

8. SARTON, GeORGE. Introduction to the History of Science (Baltimore, Md., 1927), 574; and Khairaliah, Amin A. Outline of Arabic Contribution to Medicine (Beirut, 1946), 105.

9. Brogkelmann, Garl. Geschichte der Arabischen Litteratur (x, Leiden, 1943), 224.

10. UȘA YBI 'AH, 'Uȳunn, 2, 98-100; and Bar Hebraeus, Tärikh Mukhtasar al-Duwal, ed. Antūn Salihānī (Beirut, 189o), 239, 250.

11. Muhammad IBN IstráQ ibN AL-Nadí, al-Fihrist (Cairo ed., 1930), 427; and Elgood, Gyrir. A Medical History of Persia and the Eastern Caliphate (Cambridge, 195I), 92-3.

12. See Leclerc, Histoire, $1,103-4,111$.

13. M. Boubaker ben Yahia. 'Aperçu sur la "Période Arabe" de l'Histoire de la Médecine', Les Conférences du Palais de la Découverte, Series D, No. 19 (Paris, 1952), 35 .

14. USAYBI 'AH, 'Uyūn, 2, I16-17 reports that the well favoured Jubrā 'il alKahhāl, the oculist of al-Mamūn (reigned 813-33), was equipped with the necessary tools of the oculist to perform his work efficiently. However, charlatans known as the highway oculists (Kahhālū al-T uruqāa) were numerous and eloquent in advertising their skill and products. They prepared eye-salves from starch and gum Arabic (acacia) coloured with red by the 


\section{The Rise of Professional Pharmacy in Islam}

addition of minium (red oxide of lead), green by curcuma (kurkum) and yellow by saffron. They also made other eye remedies from the Egyptian ban dissolved in gum mucilage or from the burned seeds of myrobalan mixed with pepper for spraying into the eye. Ahmad 'Isā, al-Bïmäristānāt fí al-Isläm (Damascus, 1939), 54 .

15. HUNAYN IBN ISHAQ (809-877) translated the surgical writings of Galen and wrote some of his own on the eye. Others as 'Isa ibn Māsah and Ibn Māsawayh wrote on minor surgical manipulations. See Sarton, Introduction, I, 6I r; Ușaybi 'ah, 'Uyün, 2, 136-41; and al-Qiftì, Akhbär, 249.

16. No doubt alchemy was widely practised in Iraq during the ninth century. An alchemist who is said to have worked for Al-Mamūn (813-33) was Yūsuf ibn Laqwah, Qiftī, $A k h b a ̈ r$, 129. We also read of $Y a$ 'qūb al-kind ì (d. 873) who criticized in his writings those who believed in the possibility of transmuting lesser metals into gold or silver. See Hajji Khalfah, Kashf alZunün 'an Asmā al-Kutub wa al-Funün (2, Cairo ed., 1274 A.H. [A.D. 1858]), ig6.

17. QIrTĩ , Akhbär, 129; in his treatise on Al-Adwiyah al-Mawjüdah (see note I), al-Rāzì refers to the pharmacists (al-Sayādilah) who specialized in the knowledge and compounding of the various drugs. Also VIDA, G. Levi Della in his article 'A Druggist Account on Papyrus', Archaeological Orientalia in Memoriam Emest Herzfeld, ed. George C. Miles (New York, 1952), 150-1, studied a record of purchase or sale written on this papyrus of a ninth-century educated pharmacist; several pharmaceutical preparations are mentioned.

18. Gastiglioni, Arturo. A History of Medicine, transl. E. B. Krumbhaar (New York, 1941), 281.

19. UȘA YB 'AH, 'Uyün, 2, 92-3; and BAR Hebraeus, Tärikh, 244.

20. This is why 'al-Muhtasib', the government officer authorized to inspect shops and markets against all kinds of fraud and adulteration, included in his varied responsibilities the inspection of the shops of pharmacists and 'atțārin'. He was also supposed to instruct and admonish practitioners in all branches of healing to perform their services to the best of their ability and to punish any misconduct. See Muhammad ibn al-Ukhuwwah, Ma'alim al-Qurbah $f^{i}$ Ahkām al-Hisbah, ed. Reuben Levy (Cambridge, 1938), 7, 80-6, $115-23,150-$ 69; and 'IsÄ, Bimäristänät, 57-8.

21. Many started their careers in the apothecary shop before turning to the practice of medicine. The celebrated poet Abū Nuwās (757-813) was sent by his widowed mother first to work as an apprentice in an apothecary shop at alBașrah, Iraq. Then young Abū Nuwās turned to literature and poetry and deserted pharmacy. See Ahmad al-Iskandari, et al., Al-Mufassal fi Tärikh al-Adab al-'Arabi (I, Cairo, 1934), 197.

22. Nadim, Fihrist, 454.

23. Nadim, Fïhrist, 375, 425-6; and AL-QIfTì, Akhbär, 245-6.

24. One of these works by $\mathrm{Ya}_{\mathrm{a}}$ 'qūb al-Kindī was edited, translated and annotated by Karl Garbers, Kitäb Kìmiyā al-'Itr wat-Tas 'idät, Leipzig, 1948.

25. This translation by Istifān ibn Basīl, corrected by Hunayn ibn Ishāq, was edited, translated and annotated by César E. Dubier, and Elias Terés, $\mathrm{La}$ 'Materia Médica' de Dioscorides, 5 vols., Tetuan and Barcelona, 1952-7.

26. Part seven of Kitäb al-Hẫui fí al-Tỉbb by al-Rāzi discusses Pharmacy in the Medical Art (Șaydalat al-Ṭibb); Nadim, Fihrist, 431-3. 


\section{Sami Hamarneh}

27. The introduction to this work has been edited, translated and annotated by Max Meyerhof, 'Das Vorwort zur Drogen Kunde des Beruni', in Quellen und Studien zur Geschichte der Naturwissensch. und der Med., 3 (1933), Arabic text I-I 8 and German translation and annotation pp. $1-52$. Of interest to our topic here is pp. 7-8 of the Arabic text wherein al-Birunin regrets that many in his time did not differentiate between the learned pharmacist (al-Natasi) and the uncultured ' 'attär'. Recently, Dr. Bedi N. Sehsuvaroğlu published a study of this work in an article "Abu Rayhān Bïrūin ve "Kitāb al-Șaydala", Istanbul Universit. Tip Fak. Mec., (1959), roro-30 based on the manuscript No, 149 at Bursa Library, Turkey.

28. Khayr al-Din al-Zarkalī, ed. Rasā'il Ikhwān al-Şafā (2, Cairo, 1928), 330.

29. Meyerhof, Max. 'Pharmacology During the Golden Age of Arabian Medicine', Ciba Symposia, 6 (1944), 1866-7.

30. UșA Y BI 'A H, 'Uyün, 3, 240, 257.

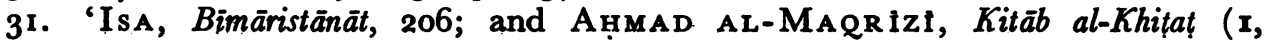
Cairo, 1853), 406. A similar pharmacy section for storing, manufacturing and compounding drugs was also instituted in the great al-Manșüri hospital of Cairo. Ibid.

32. UȘAYBI 'Aн, 'Uyün, 3, 396-7.

33. Meyerhof, Ciba Symposia, 6, I863; and Un Glossaire de Matière Médicale de Maïmonide, ed. and translated into French by Meyerhof, Cairo, 1940.

34. This work has been edited by Paul Sbath, 'Le Formulaire des Hôpitaux d'Ibn Abil-Bayan, Médecin du Bimaristan Annacery au Caire au XIIIe Siècle', Bulletin de l'Institut d'Égypte, 15 (1933), [13]-78. See also Martin Levey, 'Arabic Dental Pharmacotherapy at the Turn of the 12th Century', Janus, 49 (ig6r), [ror]-3.

35. Ishāq was also the author of the Medical work 'Nuzhat al-Nafs'. See Sulaymān ibn Juljul, Tabaqāt al-Ațibbā wa al-Hukamāa, ed. Fuād Sayyid (Cairo, 1955), 84.

36. See Sulaymān ibn Juljul, Tabaqāt al-Ațibbā wa al-Hukamā, ed. Fuād Sayyid (Cairo, 1955), 88-9.

37. Sa'id ibN Agmad al-Andalust, Tabaqat al-Umam, ed. Louis Cheikho (Beirut, 1912), 78, 80; and I BN Jul Jú , Atibbä, 93-7.

38. IBN JULJUL, Atibbā, I I2-14.

39. UȘA Y BI 'AH, 'Uyün, 3, 128-9.

40. KHALFAн, Kashf, I, 318 .

4I. 'Abd al-Waḥid al-Marrākushī, al-Mu'jib fi Talkhị Akhbār al-Maghrib, ed. R. Dozy (2nd ed., Leiden, 188I), 208-10.

42. A work entitled Tuhfat al-Aḥbāb: Glossaire de La Matière Médicale Morocaine, edited by H. P. J. Renaud and Georges S. Colin, Paris, 1934, shows a sample of this continued tradition.

43. For more detail on the significance of this 1240 edict, see KREMERS, EDWARD and URDANG, GeORGe, History of Pharmacy: $A$ Guide and a Survey (2nd rev. ed., Philadelphia, 195I), 49-50.

44. For the development of professional pharmacy in Christian Spain see Rafael Folch Andréa, 'L'Enseignment Pharmaceutique en Espagne du Moyen Âge à nos Jours', Revue d'Histoire de la Pharmacie, 48, No. I67 (196I), 425-6. 